University of Nebraska - Lincoln

DigitalCommons@University of Nebraska - Lincoln

1984

\title{
EFFECTS OF CASTRATION AND ELECTRICAL STIMULATION ON BEEF CARCASS QUALITY AND PALATABILITY CHARACTERISTICS
}

\author{
S. Kalstrup \\ Danish Meat Research Institute \\ H. R. Cross \\ Texas A \& M University - College Station \\ B. D. Schanbacher \\ USDA-ARS \\ R. W. Mandigo \\ USDA-ARS, rmandigo1@unl.edu
}

Follow this and additional works at: https://digitalcommons.unl.edu/usdaarsfacpub

Part of the Agricultural Science Commons

\begin{abstract}
Kalstrup, S.; Cross, H. R.; Schanbacher, B. D.; and Mandigo, R. W., "EFFECTS OF CASTRATION AND ELECTRICAL STIMULATION ON BEEF CARCASS QUALITY AND PALATABILITY CHARACTERISTICS" (1984). Publications from USDA-ARS / UNL Faculty. 767.

https://digitalcommons.unl.edu/usdaarsfacpub/767
\end{abstract}

This Article is brought to you for free and open access by the U.S. Department of Agriculture: Agricultural Research Service, Lincoln, Nebraska at DigitalCommons@University of Nebraska - Lincoln. It has been accepted for inclusion in Publications from USDA-ARS / UNL Faculty by an authorized administrator of DigitalCommons@University of Nebraska - Lincoln. 


\title{
EFFECTS OF CASTRATION AND ELECTRICAL STIMULATION ON BEEF CARCASS QUALITY AND PALATABILITY CHARACTERISTICS
}

\author{
US Department of Agriculture 3,4 \\ Clay Center, NE 68933; \\ Danish Meat Research Institute, \\ Roskilde, Denmark \\ and \\ University of Nebraska, \\ Lincoln 68583
}

S. Klastrup ${ }^{1}$, H. R. Cross $^{2}$, B. D. Schanbacher ${ }^{3}$ and R. W. Mandigo ${ }^{4,5}$

\section{Summary}

Thirty bull and 30 heifer Hereford $x$ Simmental calves were weaned at approximately 5 mo of age and assigned randomly to one of the following treatments: intact, conventionally castrated or luteinizing hormone-releasing hormone-immunized (LHRH). All animals were slaughtered at 16 mo of age and the right side of each carcass was electrically stimulated (ES) or restimulated (RES). Yield and quality grades were determined on both right and left sides after $24 \mathrm{~h}$ chilling. Longissimus muscles (LD) were obtained at $7 \mathrm{~d}$ postmortem for objective color measurements, chemical analysis, shear force and trained sensory panel evaluation. Semitendinosus muscles (ST) were also obtained at $7 \mathrm{~d}$ postmortem for shear evaluation. Differences among the three male groups in quality grade scores and lean color were nonsignificant, but bull and LHRH-bull carcasses were leaner with a higher percentage protein when compared with steer carcasses. Shear values for both $L D$ and ST muscles indicated that steers had more tender meat than bulls and LHRH-treated males. Collagen content and

\footnotetext{
${ }^{1}$ Danish Meat Research Institute, Roskilde, Denmark.

${ }^{2}$ Present address: Meats and Muscle Biology Section, Anim. Sci. Dept., Texas A\&M Univ., College Station 77840 .

${ }^{3}$ USDA, ARS, Roman L. Hruska U.S. Meat Animal Research Center, Clay Center, NE 68933.

${ }^{4} 202$ Loeffel Meat Lab, College of Agriculture, Univ. of Nebraska, Lincoln 68583.

${ }^{5}$ The assistance of Alison McCartney, Research Technician and Marilyn Stones, Secretary, is gratefully acknowledged,

Received February 11, 1983.

Accepted June 16, 1983.
}

sensory panel scores for tenderness were only slightly in favor of the steers. Ovariectomized heifers had less subcutaneous fat and were rated more tender by the sensory panel than intact and LHRH-treated females. The LHRH-treated females had higher shear values for the LD muscle. These were the only differences in carcass and meat characteristics among the three female groups. Females had slightly higher yield grades, higher USDA quality grades and were fatter than steers. Electrical stimulation resulted in less severe 'heat ring' formation, more youthful lean maturity scores, brighter lean color and improved shear values of ST meat. Electrical stimulation had no effect on tenderness of LD meat. Sex $x$ stimulation interactions were due to a better response of steers to ES than in the other groups.

(Key Words: Beef, Sex, Immuno-Castration, Electrical Stimulation, Palatability.)

\section{Introduction}

Traditionally, meat-producing animals are castrated in the United States because they are more acceptable to current management systems and allow the production of a carcass lending itself to traditional U.S. marketing. Castrated animals are also easier to handle, deposit fat more readily and are generally marketed at a younger age (Field, 1971; Seideman et al., 1982) than noncastrates. Conventional methods of castration are stressful and can lead to serious setbacks in the efficient production of animal products. It has been, however, well documented (Field, 1971; Seideman et al., 1982) that bulls grow more rapidly, utilize feed more efficiently and produce a higher yielding carcass with less outside fat and more edible product than steers. 
Field (1971) and Seideman et al. (1982) also show in their reviews that bulls, compared with steers, have less marbling, lower USDA quality grade, darker lean color and meat that is less tender.

The advantages of young bulls as efficient producers of lean meat are well documented but they have not been accepted in the marketplace because of problems presumably associated with behavior (resulting in dark muscle color) and meat tenderness. Thus, meat production from intact animals has encountered strong resistance in traditional marketing channels. Causes for the reduced tenderness in young bulls have not been fully revealed, but appear to be related to the state of muscle contraction or cold shortening and the amount and strength of intramuscular collagen. Limited data (Boccard et al., 1979) indicates that collagen toughness in bulls may be linked to sexual development and the associated increase in circulatory androgens.

Some of the problems associated with bull beef might be resolved with postmortem treatments. The cold shortening or myofibrillar effects on tenderness could perhaps be offset with electrical stimulation (ES) as reported by Riley et al. (1983); whereas, the collagen effects on tenderness may be alleviated by cooler aging as reported by Crouse et al. (1983).

The gonads, both testes and ovaries, secrete steroids that influence performance traits of feedlot cattle. For example, testosterone appears to stimulate rate of gain and feed conversion efficiency in the male; however, this hormone can stimulate sexual behavior resulting in poorer performance. On the other hand, ovarian hormones and cyclicity in the female are thought to decrease the performance of feedlot heifers. As a result, ovariectomy and feeding of melengestrol acetate (MGA) to intact heifers to inhibit estrous activity has been practiced. Recently, Schanbacher (1982) reported that castration effects were obtained in ram lambs actively immunized against luteinizing hormone-releasing hormone (LHRH). These lambs were characterized by low serum concentrations of testosterone and carcass characteristics typical of castrates.

The objectives of this study were to evaluate the combined effects of conventional or immunological castration with postmortem electrical stimulation treatments (electrical stimulation and restimulation) on carcass and meat traits of the male and female bovine. Growth and feed utilization by these cattle were previously described by Gettys et al. (1982).

\section{Experimental Procedure}

Treatment of Calves. Thirty bull and 30 heifer Hereford $\times$ Simmental calves were weaned at approximately 5 mo of age and assigned randomly to three treatment groups for males and females, respectively. Group 1 bull calves were left intact, group 2 bull calves were castrated by a conventional knife method, group 3 bull calves were immunized against LHRH, group 4 heifer calves were left intact, group 5 heifer calves were ovariectomized (OVX) and group 6 heifer calves were immunized against LHRH. Treatments involving immunizations (groups 3 and 6) consisted of injecting $200 \mu \mathrm{g}$ of LHRH antigen initially (intramuscular) and a booster injection at approximately $8 \mathrm{mo}$ of age. All calves were penned by group and fed a standard growingfinishing diet ad libitum until slaughter (16 mo of age).

Postmortem Treatments. All animals were slaughtered at the Roman L. Hruska U.S. Meat Animal Research Center abattoir. At 1 h postmortem, the right sides were ES with 1.5 $A, 280$ to $350 \mathrm{~V}$ current $(\mathrm{AC}, 60 \mathrm{~Hz})$ for a total of 50 impulses ( $1 \mathrm{~s}$ on and $.5 \mathrm{~s}$ off). One-half of group 3 (LHRH) bulls, one-half of group 6 (LHRH) heifers and one-half of group 5 (OVX) heifers were restimulated (RS) $10 \mathrm{~min}$ after the initial ES treatment using the same electrical characteristics. All sides were held at $2 \mathrm{C}$ for 24 $h$ when they were evaluated for carcass quality and yield traits. At $7 \mathrm{~d}$ postmortem, the longissimus (LD) and the semitendinosus (ST) muscles were removed from both sides of each carcass.

Hunter Color Analysis. At 7 d postmortem, $1.5-\mathrm{cm}$ thick steaks were cut from the LD at the 13 th rib - 1st lumbar vertebrae location from both sides of each carcass. Each steak was wrapped with polyvinylchloride film exposed to air for $80 \mathrm{~min}$ at $4 \mathrm{C}$ before measuring on a Hunter colorimeter (Boccard et al., 1981). The following measurements were obtained: lightness $(\mathrm{L})$, redness $\left(\mathrm{a}_{\mathrm{L}}\right)$ and yellowness $\left(\mathrm{b}_{\mathrm{L}}\right)$. The remainder of the LD muscle was frozen at $-30 \mathrm{C}$ and later cut into steaks for subsequent collagen, shear force and sensory analysis.

Rib Composition. The 9-10-11th rib section (Hankins and Howe, 1946) of the left side was removed on the 7 th $d$ postmortem, weighed and separated into lean, fat and bone. The soft 
tissue was thoroughly ground (lean and fat together), mixed three times and subsampled in duplicate for moisture and fat analysis in accordance to methods outlined by AOAC (1975). Protein content was determined by difference less $1 \%$ for ash.

Collagen Analysis. A LD steak from the left side of each animal was ground after removal of subcutaneous fat and epimysium. Four grams of each sample was analyzed for the amount of total, soluble and insoluble collagen according to the procedure described by Hill (1966). The content of hydroxyproline was determined by the spectrophotometric method described by Bergman and Loxley (1963). Total collagen content was computed by multiplying the hydroxyproline content of the residue by 7.25 and that of the supernatant by 7.52 (Cross et al., 1973).

Cooking and Pbysical Properties. Individually wrapped frozen steaks or roasts were allowed to equilibrate to $5 \mathrm{C}$ over a $24-\mathrm{h}$ period for the LD steaks and $48 \mathrm{~h}$ for the ST roasts. Thawed steaks were broiled at $275 \mathrm{C}$ on electric Faberware broilers (model $450 \mathrm{~A}$ ) to an internal temperature of $70 \mathrm{C}$. Steaks were placed $5.0 \mathrm{~cm}$ from the heat source and turned at their temperature midpoint. The ST roasts were roasted in a South Bend convection oven at a temperature of $135 \mathrm{C}$ to a final internal temperature of $70 \mathrm{C}$. Temperature was monitored with teflon-coated ironconstantan thermocouples and a Honeywell recorder. Extent of cooking was evaluated 5 min after sectioning by the use of color photographic scales, with $8=$ rare and $1=$ extremely well done (AMSA, 1978). Total cooking losses for each steak were determined by calculating the differences between frozen and cooked weights.

Instron Measurements. After cooking in a manner identical to that described above, samples for the Instron were held at $5 \mathrm{C}$ until the internal temperature was $5 \mathrm{C}$. Equilibration required about $26 \mathrm{~h}$ for the $\mathrm{LD}$ steaks and about $48 \mathrm{~h}$ for the ST roasts. Six $1.3 \mathrm{~cm}$ diameter meat cores taken parallel to the muscle fibers were removed from each sample. Each core was sheared once with an Instron Model 1132 equipped with a Warner-Bratzler shear attachment. The Instron was programmed to have a fail criterion of $75 \%$, a chart speed of $20 \mathrm{~cm} / \mathrm{min}$ and a crosshead speed of $5 \mathrm{~cm} / \mathrm{min}$. The three measurements taken were: 1) peak force, which is the maximum force in $\mathrm{kg}$ required to shear a sample; 2 ) peak elongation defined as the distance in $\mathrm{cm}$ traveled by the shear blade from first contacting the sample to the peak force point; 3 ) fail energy, defined as the total work (area) under the forcedeformation curve.

Sensory Panel Evaluation. Immediately after cooking, two samples $(1.3 \times 1.3 \times 1.9 \mathrm{~cm})$ from each steak were served, without reheating, to each of the 12 members of the descriptive attribute panel. Panelists were selected and trained by procedures outlined by Cross et al. (1978). Panelists evaluated each sample for tenderness, juiciness, connective tissue and flavor intensity, using an 8-point structured scale with $8=$ extremely tender, juicy, no connective tissue and intense flavor.

Statistical Analysis. Data were analyzed by analysis of variance. The model used on results from the left sides included the fixed effect of sex condition and the covariance of time from stunning to stimulation. Data obtained from both sides were analyzed with a model including the fixed effects of sex condition, animal within sex, stimulation and the interaction between sex condition and stimulation. The Statistical Analysis System was used to compute the analysis of variance (SAS, 1979).

\section{Results and Discussion}

Sex Effects. Results for longissimus and carcass traits are shown in table 1. As expected, steers had significantly lower carcass side weights, smaller rib eye areas, slightly greater fat thickness measurements and poorer yield grades than the two other male groups. Field (1971) and Seideman et al. (1982) reported similar differences between steers and bulls.

The marbling score was slightly higher for steers than for bulls, but the difference was not significant. Similar results were reported for bulls and steers slaughtered at the same age (Wilson et al., 1974); Albaugh et al., 1975), while Arthaud et al. (1977) reported that steers slaughtered at 15,18 and 24 mo had significantly higher marbling scores than bulls slaughtered at the same ages.

There was no difference between the three male groups in lean texture, lean maturity or lean color rating as well as lightness and saturation measured on the Hunter colorimeter. If bulls are not stressed before slaughter, color has been shown to be no problem (Field, 1971). Using objective measurements of color, the LD from bulls and steers were found to be similar in lightness (Kousgaard and Klastrup, 1980). 
TABLE 1. LEAST-SQUARES MEANS FOR LONGISSIMUS MUSCLE AND CARCASS TRAITS

\begin{tabular}{|c|c|c|c|c|c|c|}
\hline Trait (non-ES sides) & Bulls & Steers & $\begin{array}{l}\text { LHRH- } \\
\text { bulls }\end{array}$ & Heifers & $\begin{array}{l}\text { OVX } \\
\text { heifers }\end{array}$ & $\begin{array}{l}\text { LHRH- } \\
\text { heifers }\end{array}$ \\
\hline $\begin{array}{l}\text { Number } \\
\text { Side weight, } \mathrm{kg} \\
\text { Rib eye area, } \mathrm{cm}^{2} \\
\text { Adj. fat thickness, cm } \\
\text { Kidney, pelvic and heart } \\
\text { fat, \% } \\
\text { USDA yield grade } \\
\text { Lean texture } \\
\text { Lean maturity } \\
\text { Marbling } \\
\text { USDA quality grade } \\
\text { Lean color } \\
\text { Hunter - Lightness } \\
\text { Saturationg } \\
\text { Hue }\end{array}$ & $\begin{array}{c}1.4^{\mathrm{a}} \\
1.7^{\mathrm{d}} \\
5.3^{\mathrm{ab}} \\
\mathrm{A}^{48 \mathrm{ab}} \\
\mathrm{SI}^{48} \mathrm{a} \\
\mathrm{Gd} \\
\quad 4.8^{\mathrm{ab}} \\
34.1^{\mathrm{a}} \\
17.4^{\mathrm{a}} \\
25.9^{\mathrm{a}}\end{array}$ & $\begin{array}{c}10 \\
146^{\mathrm{b}} \\
73.7^{\mathrm{c}} \\
.71^{\mathrm{ab}} \\
\\
1.6^{\mathrm{ab}} \\
2.3^{\mathrm{bc}} \\
5.2^{\mathrm{a}} \\
\mathrm{A}^{59} \mathrm{a} \\
\mathrm{Sl}^{99} \mathrm{ab} \\
\mathrm{Gd}^{+} \\
4.4^{\mathrm{a}} \\
33.3^{\mathrm{a}} \\
16.4^{\mathrm{a}} \\
26.1^{\mathrm{a}}\end{array}$ & $\begin{array}{l}10 \\
168^{\mathrm{a}} \\
87.0^{\mathrm{a}} \\
.59^{\mathrm{a}} \\
\\
2.0^{\mathrm{bc}} \\
2.0^{\mathrm{cd}} \\
5.6^{\mathrm{abc}} \\
\mathrm{A}^{57 \mathrm{a}} \\
\mathrm{Sl}^{51 \mathrm{a}} \\
\mathrm{G} \\
4.6^{\mathrm{a}} \\
33.3^{\mathrm{a}} \\
16.6^{\mathrm{a}} \\
27.4^{\mathrm{bc}}\end{array}$ & $\begin{array}{l}10 \\
147^{\mathrm{b}} \\
75.4^{\mathrm{bc}} \\
1.08^{\mathrm{c}} \\
\\
2.6^{\mathrm{d}} \\
2.8^{\mathrm{a}} \\
5.8^{\mathrm{bcd}} \\
\mathrm{A}^{35 \mathrm{bc}} \\
\mathrm{Sm}^{33 \mathrm{~b}} \\
\mathrm{Ch}- \\
5.7^{\mathrm{c}} \\
33.1^{\mathrm{a}} \\
16.9^{\mathrm{a}} \\
26.5^{\mathrm{ab}}\end{array}$ & $\begin{array}{c}9 \\
136^{\mathrm{b}} \\
69.8^{\mathrm{c}} \\
.81^{\mathrm{ab}} \\
2.6^{\mathrm{d}} \\
2.6^{\mathrm{ab}} \\
6.2^{\mathrm{d}} \\
\mathrm{A}^{33 \mathrm{bc}} \\
\mathrm{Sm} \mathrm{m}^{33 \mathrm{~b}} \\
\mathrm{Ch}- \\
6.0^{\mathrm{c}} \\
34.1^{\mathrm{a}} \\
17.3^{\mathrm{a}} \\
26.1^{\mathrm{a}}\end{array}$ & $\begin{array}{c}9 \\
146^{\mathrm{b}} \\
81.0^{\mathrm{b}} \\
.91^{\mathrm{bc}} \\
2.2^{\mathrm{cd}} \\
2.3^{\mathrm{bcd}} \\
6.1^{\mathrm{cd}} \\
\mathrm{A}^{32 \mathrm{c}} \\
\mathrm{Sm}^{27} \mathrm{~b} \\
\mathrm{Ch}- \\
5.5^{\mathrm{bc}} \\
33.9^{\mathrm{a}} \\
17.1^{\mathrm{a}} \\
27.9^{\mathrm{c}}\end{array}$ \\
\hline
\end{tabular}

a,b,c,d $V$ alues in the same row bearing different superscripts $\operatorname{differ}(P<.05)$.

Scored: 1 = very coarse to 7 = very fine.

f Scored: 1 = black to 7 = very light cherry red.

$\mathrm{g}_{\text {Saturation }}=\left(\mathrm{a}_{\mathrm{L}}{ }^{2}+\mathrm{b}_{\mathrm{L}^{2}}\right)^{1 / 2}$.

$h_{\text {Hue }}=\tan ^{-2} \frac{\left(b_{L}\right)}{\left(a_{L}\right)}$.

Others (Arthaud et al., 1977; Crouse et al., 1983) found that steers have a more desirable lean color rating as compared with bulls. If the muscle glycogen had been depleted antemortem because of stress, it would likely result in a higher ultimate muscle $\mathrm{pH}$ and an unacceptable dark muscle color. The results reported by Crouse et al. (1983) indicate that bulls have a higher frequency of dark-cutters than steers.

Ovariectomized heifers had slightly smaller rib eye areas and less outisde fat when compared with the two other female groups.
Brannang (1971) found OVX heifers to have $6 \%$ lighter body weight than intact heifers. Lean color ratings and USDA quality grades were similar for the intact, OVX and LHRHimmunized females. Marchello et al. (1970) reported that OVX heifers were similar to intact heifers in marbling scores, but had lower conformation grades.

Steers were similar to the female groups in carcass side weights and rib eye areas, but subcutaneous fat was less. The females had higher USDA yield grades (less edible product)

TABLE 2. LEAST-SQUARES MEANS FOR CHEMICAL ANALYSIS

\begin{tabular}{|c|c|c|c|c|c|c|}
\hline Traits & Bulls & Steers & $\begin{array}{l}\text { LHRH } \\
\text { bulls }\end{array}$ & Heifers & $\begin{array}{l}\text { OVX } \\
\text { heifers }\end{array}$ & $\begin{array}{l}\text { LHRH } \\
\text { heifers }\end{array}$ \\
\hline $\begin{array}{l}\text { Soft tissue from } \\
9-10-11 \text { th rib section }\end{array}$ & & & & & & \\
\hline $\begin{array}{l}\% \text { moisture } \\
\% \text { fat } \\
\% \text { protein }\end{array}$ & $\begin{array}{l}57.3^{\mathrm{a}} \\
23.6^{\mathrm{a}} \\
18.1^{\mathrm{a}}\end{array}$ & $\begin{array}{l}53.9^{\mathrm{b}} \\
29.4^{\mathrm{b}} \\
15.8^{\mathrm{bc}}\end{array}$ & $\begin{array}{l}57.2^{\mathrm{a}} \\
25.2^{\mathrm{a}} \\
16.6^{\mathrm{b}}\end{array}$ & $\begin{array}{l}49.2^{\mathrm{c}} \\
35.3^{\mathrm{c}} \\
14.5^{\mathrm{d}}\end{array}$ & $\begin{array}{l}49.1^{\mathrm{c}} \\
35.5^{\mathrm{c}} \\
14.4^{\mathrm{d}}\end{array}$ & $\begin{array}{l}49.7^{\mathrm{c}} \\
34.5^{\mathrm{c}} \\
14.8^{\mathrm{cd}}\end{array}$ \\
\hline $\begin{array}{l}\text { Longissimus muscle } \\
\text { Total collagen, } \mathrm{mg} / \mathrm{g} \\
\text { Soluble collagen, } \%\end{array}$ & $\begin{array}{c}4.59^{\mathrm{a}} \\
21.0^{\mathrm{a}}\end{array}$ & $\begin{array}{l}3.83^{\mathrm{ab}} \\
17.2^{\mathrm{ab}}\end{array}$ & $\begin{array}{r}4.26^{\mathrm{a}} \\
19.0^{\mathrm{ab}}\end{array}$ & $\begin{array}{l}3.30^{\mathrm{b}} \\
16.7^{\mathrm{b}}\end{array}$ & $\begin{array}{r}3.31^{\mathrm{b}} \\
17.3^{\mathrm{ab}}\end{array}$ & $\begin{array}{l}3.22^{\mathrm{b}} \\
16.4^{\mathrm{b}}\end{array}$ \\
\hline
\end{tabular}

$a, b, c, d$ Values in the same row bearing different superscripts differ $(P<.05)$. 
and higher USDA quality grades than the males. Marchello et al. (1970) also reported that steers had less subcutaneous fat and produced more saleable retail meat than heifers. Marion et al. (1980) reported that steers and heifers were similar in both quality and yield grades.

The soft tissue from bulls contained $3.4 \%$ more moisture, $5.8 \%$ less fat and $2.3 \%$ more protein than the soft tissue from steers (table 2). These results agree with results found by Glimp et al. (1971). The LHRH bulls had a moisture content similar to the intact bulls, while percentage fat and protein contents were intermediate between bull and steer carcasses. The heifers did not differ from one another in percentage moisture, fat or protein. Ocariz et al. (1970) also did not report any significant differences between intact and OVX heifers in chemical composition. The soft tissue from the females contained less moisture and protein and more fat compared with the males. Although
Marion et al. (1980) found no difference in crude protein between steers and heifers, steers had less fat (35.8 vs $38.3 \%)$ and more water (49.02 vs $46.48 \%)$ than heifers.

The amount of total intramuscular LD collagen and heat soluble collagen was slightly lower in steers than bulls (table 2). The females were similar for content of total and soluble collagen. Bull and LHRH-treated bull carcasses contained significantly more total collagen than females. The proportion of heat soluble collagen was significantly higher in bulls compared with heifers and LHRH-treated heifers. Sorensen (1981) reviewed the influence of sex on collagen and reported that the majority of the data points toward a generally higher content of collagen in bulls than in male castrates or females.

Instron shear force measurements and trained sensory panel results are presented in table 3. Longissimus muscle steaks from bulls

TABLE 3. LEAST-SQUARES MEANS FOR SENSORY EVALUATION AND SHEAR FORCE

\begin{tabular}{|c|c|c|c|c|c|c|}
\hline Item (non-ES sides) & Bulls & Steers & $\begin{array}{l}\text { LHRH- } \\
\text { bulls }\end{array}$ & Heifers & $\begin{array}{l}\text { OVX } \\
\text { heifers }\end{array}$ & $\begin{array}{l}\text { LHRH- } \\
\text { heifers }\end{array}$ \\
\hline \multicolumn{7}{|l|}{ WB shear of LH } \\
\hline Peak force, kg & $4.63^{\mathrm{a}}$ & $3.71^{\mathrm{b}}$ & $4.48^{a}$ & $3.63^{b}$ & $3.44^{b}$ & $4.67^{\mathrm{a}}$ \\
\hline Peak elongation, $\mathrm{cm}$ & $1.17^{\mathrm{a}}$ & $1.20^{\mathrm{a}}$ & $1.12^{\mathrm{a}}$ & $1.17^{\mathrm{a}}$ & $1.15^{\mathrm{a}}$ & $1.13^{\mathrm{a}}$ \\
\hline Fail energy, $\mathrm{cm} \times \mathrm{kg}$ & $3.76^{a}$ & $3.01^{b}$ & $3.65^{\mathrm{a}}$ & $3.41^{\mathrm{ab}}$ & $2.99 \mathrm{~b}$ & $3.79^{\mathrm{a}}$ \\
\hline \multicolumn{7}{|l|}{ WB shear of ST } \\
\hline Peak force, $\mathrm{kg}$ & $4.51^{\mathrm{ab}}$ & $3.96^{\mathrm{b}}$ & $4.87^{a}$ & $4.70^{\mathrm{ab}}$ & $4.65^{\mathrm{ab}}$ & $4.37^{\mathrm{ab}}$ \\
\hline Peak elongation, $\mathrm{cm}$ & $.88^{b}$ & $.98^{\mathrm{ab}}$ & $.99^{\mathrm{a}}$ & $.99^{a b}$ & $.97^{\mathrm{ab}}$ & $1.02^{\mathrm{a}}$ \\
\hline Fail energy, $\mathrm{cm} \times \mathrm{kg}$ & $4.17^{\mathrm{a}}$ & $3.47^{\mathrm{a}}$ & $4.09^{a}$ & $4.19^{\mathrm{a}}$ & $4.30^{\mathrm{a}}$ & $3.72^{\mathrm{a}}$ \\
\hline Fail force, $\mathrm{kg}$ & $1.11^{\mathrm{ab}}$ & $.98^{b}$ & $1.21^{\mathrm{ab}}$ & $1.21^{\mathrm{a}}$ & $1.21^{\mathrm{ab}}$ & $1.08^{\mathrm{ab}}$ \\
\hline \multicolumn{7}{|l|}{ Sensory evaluation of LD } \\
\hline Juiciness $\mathrm{d}$ & $5.2^{\mathrm{ab}}$ & $5.3^{\mathrm{ab}}$ & $5.0^{\mathrm{a}}$ & $5.5^{b}$ & $5.3 \mathrm{ab}$ & $5.4^{\mathrm{ab}}$ \\
\hline Ease of fragmentation $\mathrm{e}$ & $5.1^{\mathrm{ab}}$ & $5.4^{\mathrm{bc}}$ & $4.9^{\mathrm{a}}$ & $5.3^{\mathrm{b}}$ & $5.7^{\mathrm{c}}$ & $5.3^{\mathrm{b}}$ \\
\hline Amount of connective tissue $f$ & $4.8^{\mathrm{ab}}$ & $5.2^{\mathrm{bc}}$ & $4.8^{\mathrm{a}}$ & $5.0^{\mathrm{ab}}$ & $5.4^{\mathrm{c}}$ & $5.0^{\mathrm{ab}}$ \\
\hline Tenderness 8 & $5.1^{\mathrm{ab}}$ & $5.4^{b c}$ & $4.9^{a}$ & $5.3^{\mathrm{ab}}$ & $5.7^{\mathrm{c}}$ & $5.2^{\mathrm{bc}}$ \\
\hline Flavor ${ }^{h}$ & $5.3^{2}$ & $5.3^{\mathrm{a}}$ & $5.0^{\mathrm{a}}$ & $5.2^{\mathrm{a}}$ & $5.3^{\mathrm{a}}$ & $5.3^{\mathrm{a}}$ \\
\hline \multicolumn{7}{|l|}{ Cooking Properties } \\
\hline Extent of cookingi, LD & $4.2^{\mathrm{a}}$ & $4.0^{\mathrm{a}}$ & $4.3^{\mathrm{ab}}$ & $4.1^{\mathrm{a}}$ & $4.3^{\mathrm{ab}}$ & $4.9 \mathrm{~b}$ \\
\hline Cooking loss, LD & $28.9^{\mathrm{a}}$ & $28.5^{a}$ & $30.4^{\mathrm{a}}$ & $28.9^{a}$ & $31.0^{\mathrm{a}}$ & $30.0^{\mathrm{a}}$ \\
\hline Cooking loss, ST & $31.6^{\mathrm{ab}}$ & $29.5 \mathrm{bc}$ & $32.8^{\mathrm{a}}$ & $26.6^{\mathrm{c}}$ & $27.0^{\mathrm{c}}$ & $27.2^{\mathrm{c}}$ \\
\hline
\end{tabular}

$a, b, c$ Values in the same row bearing different superscripts differ $(P<.05)$.

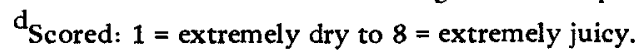

Scored: 1 = extremely difficult to 8 = extremely easy.

Scored: 1 = abundant to 8 = none.

$\mathrm{g}_{\text {Scored: }} \mathbf{1}=$ extremely tough to $8=$ extremely tender.

$h^{h}$ Scored: $1=$ extremely bland to $8=$ extremely intense.

$\mathbf{i}_{4}=$ medium, $5=$ well done. 
required higher peak force (maximum force) and fail energy to be sheared as compared with LD steaks from steers. Semitendinosus muscles from bulls had a higher cooking loss and required slightly more peak force to be sheared than ST muscles from steer carcasses. Meat from bulls also had slightly lower scores for ease of fragmentation, amount of connective tissue (indicative of more connective tissue) and overall tenderness ratings compared with meat from steers. Luteinizing hormone-releasing hormone bull beef was quite similar to intact bull beef in regard to shear and sensory measurements for tenderness.

Meat from OVX heifers had higher taste panel scores for tenderness than meat from the two other female groups. The female groups were also similar for the shear measurements of the ST roasts, but the LHRH-treated heifers had higher shear measurements for LD steaks as compared with intact and OVX heifers. Bouton et al. (1982) did not find any differences in LD shear force between intact and OVX heifers. Meat from steers had the same magnitude of shear force values and sensory evaluations for the LD steaks and ST roasts as the intact and OVX heifers. Meat from steers had higher cooking losses for the ST roasts than roasts from females. Buchter (1974) and Marion et al. (1980) also reported no significant tenderness differences between steers and heifers.

There were no differences between sexes in sensory evaluation scores for flavor and juiciness. Field (1971) found that the taste panel differences for juiciness and flavor are small or nonexistent between bulls and steers. Reagan et al. (1971) and Crouse et al. (1983) found that bulls had less intense meat flavor than steers possibly because of the greater effect of preslaughter stress on the ultimate $\mathrm{pH}$ of the bull muscles.

Effect of Electrical Stimulation. Electrical stimulation (ES) resulted in carcass sides that had less severe 'heat ring' formation and more youthful lean and skeletal maturity scores $24 \mathrm{~h}$ postmortem compared with control sides (table 4). The ES sides had brighter lean color scores (subjective evaluation) and, after $7 \mathrm{~d}$ poststimulation, had higher saturation (more intense red color) and greater hue (contains a greater amount of yellow, which cause a lighter color impression) Hunter readings. Cross (1979)

TABLE 4. LEAST-SQUARES MEANS FOR GRADING AND HUNTER MEASUREMENT OF THE LONGISSIMUS MUSCLE FROM CONTROL AND STIMULATED SIDES

\begin{tabular}{|c|c|c|c|c|}
\hline \multirow[b]{2}{*}{ Trait } & \multirow[b]{2}{*}{ Control } & \multirow[b]{2}{*}{ Stimulated } & \multicolumn{2}{|c|}{ Statistical significance } \\
\hline & & & Stimulation & $\begin{array}{l}\text { Sex } X \\
\text { stimulation }\end{array}$ \\
\hline Number & 44 & 44 & & \\
\hline Heat ring ${ }^{2}$ & 3.8 & 4.5 & $*$ & NS $^{\mathrm{d}}$ \\
\hline Lean firmness $b$ & 5.4 & 5.3 & NS & NS \\
\hline Lean texturec & 5.7 & 5.9 & NS & NS \\
\hline Lean maturity & $A^{44}$ & $A^{35}$ & $* *$ & NS \\
\hline Skeletal maturity & $A^{53}$ & $A^{48}$ & $\bullet$ & NS \\
\hline Marbling & $\mathrm{Sm}^{01}$ & $\mathrm{Sm}^{07}$ & NS & NS \\
\hline USDA quality grade & $\mathrm{Ch}^{14}$ & $\mathrm{Ch}^{13}$ & NS & $*$ \\
\hline Lean color $\mathrm{c}$ & 5.2 & 5.7 & $*$ & NS \\
\hline \multicolumn{5}{|l|}{ Hunter } \\
\hline Lightness & 33.8 & 33.4 & NS & NS \\
\hline Saturation & 16.9 & 18.6 & $\cdots$ & $\cdots$ \\
\hline Hue & 26.6 & 27.3 & $* \bullet$ & NS \\
\hline
\end{tabular}

\footnotetext{
ascored: $1=50 \%$ or more, $5=$ none.

b Scored: 1 = extremely soft to 7 = very firm.

See table 1.

$\mathrm{d}_{\mathrm{NS}}=$ nonsignificant.

$* \mathrm{P}<.05$.

$* \mathrm{P}<.01$.
} 
and Seideman and Cross (1982) reported in reviews of utilization of ES to improve meat quality, that ES prevented heat ring formation and enhanced lean color and lean maturity.

The ES used in this study did not improve the scores for lean firmness, lean texture, marbling or USDA quality grade (table 4). Cross et al. (1979), Calkins et al. (1980) and Salm et al. (1981) reported that ES significantly improved lean firmness and(or) texture scores. Seideman and Cross (1982) indicated that ES increased the appearance of marbling, while Calkins et al. (1980) and Salm et al. (1981) did not report any improvement of marbling and quality grade $24 \mathrm{~h}$ postmortem. Calkins et al. (1980) concluded that the optimum chilling time for maximizing marbling score and USDA quality grade was $48 \mathrm{~h}$ for both ES and control sides.

There were significant interactions between sex and ES for USDA quality grade and Hunter saturation. Electrical stimulation resulted in an increase in USDA quality grade for steers with an increased Hunter saturation while ES resulted in a decrease in USDA quality grade for bulls. There was a tendency for a greater improvement of color uniformity (heat ring) with ES for steers and heifers than for the other groups.

Results for the effect of ES on shear force and sensory panel values are presented in table 5. The greatest influence of ES on tenderness was obtained on the ST roasts where ES had improved all shear measurements except peak elongation. Electrical stimulation did not reduce the shear force required to shear the LD steaks. In fact, the ES LD steaks required higher fail energy than the control steaks. Sensory rating for tenderness, juiciness or flavor were not significantly affected by ES.

Numerous researchers have reported improvement in tenderness of beef due to ES (Cross, 1979; Seideman and Cross, 1982). -The latter also mentioned in their review that ES increased beef flavor rating; however, they concluded that the contribution of ES to meat flavor is usually reported as either slight or nonexistent. Ray et al. (1981) found no consistent influence of ES upon tenderness of preor postrigor roasts. Crouse et al. (1983) reported no effect on tenderness and flavor of ES bulls, whereas Riley et al. (1983) found significant positive effects on bulls with less than $.7 \mathrm{~cm}$ subcutaneous fat.

TABLE 5. LEAST-SQUARES MEANS FOR WARNER-BRATZLER (WB) SHEAR FORCE AND SENSORY EVALUATION OF THE LONGISSIMUS AND SEMITENDINOSUS MUSCLES FROM CONTROL AND STIMULATED SIDES

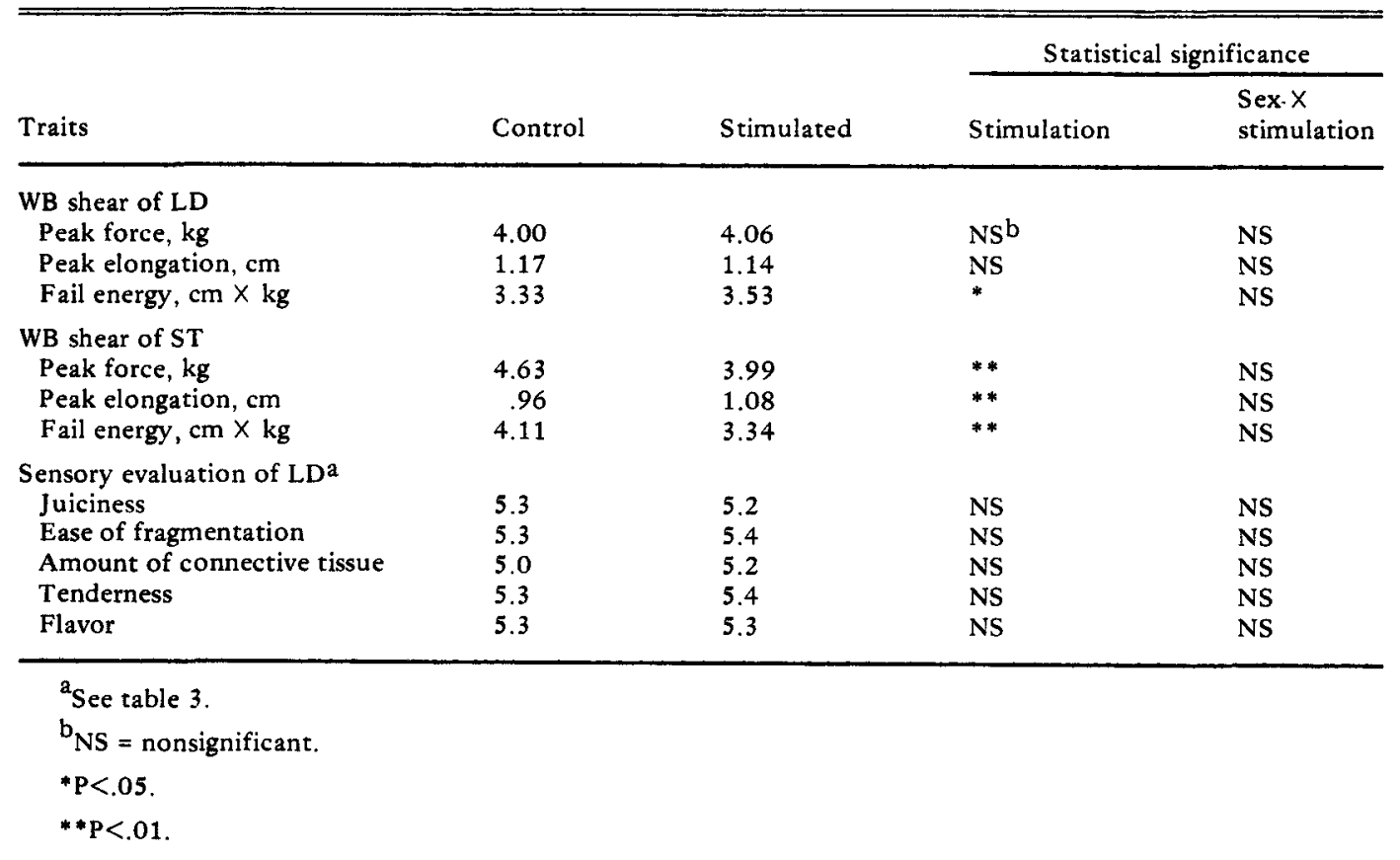


TABLE 6. LEAST-SQUARES MEANS FOR GRADING AND HUNTER MEASUREMENT OF THE LONGISSIMUS MUSCLE FROM CONTROL AND RESTIMULATED SIDES

\begin{tabular}{|c|c|c|c|c|}
\hline \multirow[b]{2}{*}{ Traits } & \multirow[b]{2}{*}{ Control } & \multirow[b]{2}{*}{ Restimulated } & \multicolumn{2}{|c|}{ Statistical significance } \\
\hline & & & Stimulation & $\begin{array}{l}\text { Sex } X \\
\text { stimulation }\end{array}$ \\
\hline Number & 14 & 14 & & \\
\hline Heat ring ${ }^{a}$ & 3.9 & 4.4 & $\mathrm{NS}^{\mathrm{c}}$ & NS \\
\hline Lean firmness ${ }^{a}$ & 5.4 & 4.8 & $*$ & NS \\
\hline Lean texturea & 5.9 & 6.0 & NS & NS \\
\hline Lean maturity & $A^{41}$ & $\mathrm{~A}^{34}$ & NS & NS \\
\hline Marbling & $\mathrm{S} 1^{95}$ & $\mathrm{Sm}^{12}$ & NS & NS \\
\hline USDA quality grade & $\mathrm{Gd}^{97}$ & $\mathrm{Ch}^{12}$ & NS & NS \\
\hline Lean color ${ }^{a}$ & 5.3 & 5.4 & NS & NS \\
\hline \multicolumn{5}{|l|}{ Hunter: $b$} \\
\hline Lightness & 33.4 & 34.2 & NS & NS \\
\hline Saturation & 17.1 & 18.3 & $*$ & NS \\
\hline Hue & 27.1 & 27.6 & $*$ & NS \\
\hline
\end{tabular}

\footnotetext{
${ }^{a}$ See table 4.

${ }^{b}$ See table 1 .

$\mathrm{c}_{\mathrm{NS}}=$ nonsignificant

$* \mathrm{P}<.05$.
}

TABLE 7. LEAST-SQUARES MEANS FOR WARNER-BRATZLER (WB) SHEAR FORCE AND SENSORY EVALUATION OF THE LONGISSIMUS AND SEMITENDINOSUS MUSCLES FROM CONTROL AND RESTIMULATED SIDES

\begin{tabular}{|c|c|c|c|c|}
\hline \multirow[b]{2}{*}{ Trait } & \multirow[b]{2}{*}{ Control } & \multirow[b]{2}{*}{ Restimulation } & \multicolumn{2}{|c|}{ Statistical significance } \\
\hline & & & Stimulation & $\begin{array}{l}\text { Sex } X \\
\text { stimulation }\end{array}$ \\
\hline \multicolumn{5}{|l|}{ WB shear of LD } \\
\hline Peak load, kg & 4.36 & 3.80 & $\mathrm{NS}^{\mathrm{b}}$ & NS \\
\hline Peak elongation, $\mathrm{cm}$ & 1.10 & 1.03 & $*$ & NS \\
\hline Fail energy, $\mathrm{cm} \times \mathrm{kg}$ & 3.62 & 3.18 & NS & NS \\
\hline \multicolumn{5}{|l|}{ WB shear of ST } \\
\hline Peak force, $\mathrm{kg}$ & 4.36 & 3.94 & $*$ & NS \\
\hline Peak elongation, $\mathrm{cm}$ & 1.03 & 1.11 & $*$ & NS \\
\hline Fail energy, $\mathrm{cm} \times \mathrm{kg}$ & 3.73 & 4.04 & NS & NS \\
\hline Fail force, $\mathrm{kg}$ & 1.08 & 1.17 & * & NS \\
\hline \multicolumn{5}{|l|}{ Sensory evaluation of LDa } \\
\hline Juiciness & 5.2 & 5.1 & NS & NS \\
\hline Ease of fragmentation & 5.3 & 5.4 & NS & NS \\
\hline Amount of connective tissue & 5.1 & 5.2 & NS & NS \\
\hline Tenderness & 5.3 & 5.3 & NS & NS \\
\hline Flavor & 5.1 & 5.2 & NS & NS \\
\hline
\end{tabular}

${ }^{a}$ See table 3 .

$\mathrm{b}_{\mathrm{NS}}=$ nonsignificant.

* $\mathrm{P}<.05$. 
Effect of Restimulation. Restimulated sides had lower lean firmness scores and higher LD Hunter color measurements for saturation and hue than control sides (table 6). In Danish experiments, it has been found that excessive ES treatments with resultant rapid $\mathrm{pH}$ decline could result in soft and exudative meat ( $L$. Buchter, personal communication). Restimulation also resulted in carcass sides with slightly more youthful lean maturity scores and slightly higher USDA quality grades $(\mathrm{P}<.05)$.

Shear force measurements from ST roasts were improved with RS with the exception of fail energy (table 7). Longissimus muscle steaks from control sides had greater peak elongation compared with LD steaks from the RS side. The other shear and sensory measurements were not affected by RS.

Restimulation has given less pronounced effect on prevention of heat rings and enhancement of lean color than initial stimulation. It appears from the data presented in tables 4 through 7 that RS had little additive effect over ES on carcass quality, shear or sensory traits.

\section{Conclusions}

Differences between bulls and steers in lean color and quality grade scores were nonsignificant. Steers had less edible product and a lower protein content as compared with bulls. Meat from steers were slightly more tender than meat from bulls.

Ovariectomy of heifers did not have a dramatic influence on their carcass and quality characteristics. Carcasses from the OVX heifers had less subcutaneous fat and were rated more tender by taste panelists than the intact heifers.

Luteinizing hormone-releasing hormone immunization resulted in carcass characteristics and palatability ratings intermediate between those of the intact and surgically-castrated bovine. Electrical stimulation improved lean color and the tenderness of ST roasts but had no tenderization effect on LD steaks. Restimulation compared with stimulation had no additive effects on carcass or palatability traits, but had a negative effect on lean firmness score.

\section{Literature Cited}

Albaugh, A., F. D. Carroll, K. W. Ellis and R. Albaugh. 1975. Comparison of carcasses and meat from steers, short scrotum bulls and intact bulls. J. Anim. Sci. 41:1627.

AMSA. 1978. Guidelines for cookery and sensory evaluation of meat. Amer. Meat Science Assoc. and Natl. Live Stock and Meat Board, Chicago, IL.

AOAC. 1975. Official Methods of Analysis (12th Ed.).
Association of Official Analytical Chemists, Washington, DC.

Arthaud, V. H., R. W. Mandigo, R. M. Koch and A. W. Kotula. 1977. Carcass composition, quality and palatability attributes of bulls and steers fed different energy levels and killed at four ages. J. Anim. Sci. 44:53.

Bergman, I. and R. Loxley. 1963. Two improved and simplified methods for the spectrophotometric determination of hydroxyproline. Anal. Chem. $35: 1961$.

Boccard, R., L. Buchter, E. Casteebs, E. Cosentins, E. Dransfield, D. E. Hood, R. L. Joseph, D. B. Macdougall, D. N. Rhodes, I. Schon, B. J. Tinbergen and C. Touraille. 1981. Procedures for measuring meat quality characteristics in beef production experiments. Report of a working group in the commission of the European Communities (CEC) beef production research programme. Livestock Prod. Sci. 8: 385 .

Boccard, R. L., R. T. Naude, D. E. Cronje, M. C. Smit, H. J. Venter and E. J. Rossouw. 1979. The influence of age, sex and breed of cattle on their muscle characteristics. Meat Sci. 3:261.

Bouton, P. E., P. V. Harris, W. R. Shorthose and G. R. Saul. 1982. A comparison of the meat properties of pasture-fed steers, heifers, pregnant heifer and sprayed heifers. Meat Sci. 6:301.

Brannang, E. 1971. Studies on monozygous cattle twins. XXIV. Some notes on the effect of ovariectomy. Swedish J. Agr. Res. 1:79.

Buchter, L. 1974. Sammerligning af kodkvaliteten hos stude, hvie og. 1. kalvskoer med kodkvaliteten hos mellemkoer. Report II no 03.182 (August 26., Kreaturer-Kodkvalitet). Danish Meat Research Institute, Roskilde, Denmark.

Calkins, C. R., J. W. Savell, G. C. Smith and C. E. Murphey. 1980. Quality-indicating characteristics of beef as affected by electrical stimulation and postmortem chilling time. J. Food Sci. 45:1330.

Cross, H. R. 1979. Effects of electrical stimulation on meat tissue and muscle properties - A review. J. Food Sci. 44:509.

Cross, H. R., Z. L. Carpenter and G. C. Smith. 1973. Effects of intramuscular collagen and elastin on bovine muscle tenderness. J. Food Sci. 38:998.

Cross, H. R., R. Moen and M. S. Stanfield. 1978. Training and testing of judges for sensory analysis of meat quality. Food Technol. 32.7:48.

Cross, H. R., G. C. Smith, A. W. Kotula and D. A. Muse. 1979. Effects of electrical stimulation and shrouding method on quality and palatability of beef carcasses. J. Food Sci. 44:1560.

Crouse, J. D., S. C. Sejdeman and H. R. Cross. 1983. The effects of carcass electrical stimulation and cooler temperature on the quality and palatability of bull and steer beef. J. Anim. Sci. 56:81.

Field, R. A. 1971. Effect of castration on meat quality and quantity. J. Anim. Sci. 32:849.

Gettys, T. W., D. M. Henricks, P. M. Burrows and B. D. Schanbacher. 1982. Growth and carcass composition in intact and gonadectomized bulls and heifers. J. Anim. Sci. 55(Suppl. 1):218.

Glimp, H. A., M. E. Dikeman, H. J. Tuma, K. E. Gregory and L. V. Cundiff. 1971. Effect of sex condition on growth and carcass traits of male Hereford and Angus cattle. J. Anim. Sci. 33:1242. 
Hankins, O. G. and P. E. Howe. 1946. Estimation of the composition of beef carcasses and cuts. USDA Tech. Bull. No. 926.

Hill, F. 1966. The solubility of intramuscular collagen in meat animals of various ages. J. Food Sci. 31:161.

Kousgaard, K. and S. Klastrup. 1980. Slagtevaegtens og foderstyrkens betydning for slagte- og kodkvalitetsegenskaker hos unztyre og stude. Report no. 01.524 (August 26., KreaturerSlagte-Og Kodkvalitet). Danish Meat Research Institute, Roskilde, Denmark.

Marchello, J. A., D. E. Ray and W. H. Hale. 1970. Carcass characteristics of beef cattle as influenced by season, sex and hormonal growth stimulants. J. Anim. Sci. 31:690.

Marion, W. F., M. E. Dikeman and A. D. Dayton. 1980. Performance and composition of steers and heifers of two biological types related to net energy for production efficiency. J. Anim. Sci. 51:882.

Ocariz, J., L. Hubard, A. Littlejohn and I. S. Robertson. 1970. A comparison of entire and ovariectomized beef heifers treated with ethylestrenol. J. Agr. Sci. (Camb.) 74:349.

Ray, E. E., D. M. Stiffler and B. W. Berry. 1981. Effects of electrical stimulation and hot boning on physical changes, cooking time and losses, and tenderness of beef roasts. J. Food Sci. 47:210.

Reagan, J. O., Z. L. Carpenter, G. C. Smith and G. T. King. 1971. Comparison of palatability traits of beef produced by young bulls and steers. J. Anim. Sci. 32:641.
Riley, R. R., J. W. Savell, C. E. Murphey, G. C. Smith, D. M. Stiffler and H. R. Cross. 1983. Palatability of beef from steer and young bull carcasses as influenced by electrical stimulation, subcutaneous fat thickness and marbling. J. Anim. Sci. $56: 592$.

Salm, C. P., E. W. Mills, E. S. Reeves, M. D. Judge and E. D. Aberle. 1981. Effect of electrical stimulation on muscle characteristics of beef cattle fed a high energy diet for varying lengths of time. $\mathrm{J}$. Food Sci. 46:1284.

SAS. 1979. SAS User's Guide. Statistical Analysis System Institute, Inc, Cary, NC.

Schanbacher, B, D. 1982. Responses of ram lambs to active immunization against testosterone and luteinizing hormone-releasing hormone. Amer. J. Physiol. 242 (Endocrinol. Metab. 5):E201.

Seideman, S. C. and H. R. Cross. 1982. Utilization of electrical stimulation to improve meat quality: $A$ review. J. Food Qual. 5:247.

Seideman, S. C., H. R. Cross, R. R. Oltjen and B. D. Schanbacher. 1982, Utilization of the intact male for red meat production: A review. J. Anim. Sci. $55: 826$.

Sorensen, S. E. 1981. Relationships between collagen properties and meat tenderness in young bulls of different genotype, weight and feeding intensity. Ph.D. Thesis. Royal Veterinary, and Agricultural Univ., Copenhagen, Denmark.

Wilson, L. L., M. C. Rugh, J. H. Ziegler and T. J.

1 McAllister. 1974. Live and carcass characteristics of Holstein castrated, short scrotum and intact males. J. Anim. Sci. 39:488. 